\title{
Portfolio Size and Diversification Effect in Lithuanian Stock Exchange Market
}

\author{
Vilija Alekneviciene $^{1}$, Egle Alekneviciute ${ }^{2}$, Rasa Rinkeviciene ${ }^{3}$ \\ ${ }^{1,3}$ Aleksandras Stulginskis University \\ Universiteto st.10, LT-53361, Kauno r., Lithuania \\ e-mail:vilija.alekneviciene@lzuu.lt,r.rinkeviciene@e-energija.lt \\ ${ }^{2}$ Vytautas Magnus University \\ Daukanto st. 28, LT-44246, Kaunas, Lithuania \\ e-mail:egle.alekneviciute@gmail.com \\ cross' $^{\text {ref }}$ http://dx.doi.org/10.5755/j01.ee.23.4.2565
}

Recently scientists have increasingly focused on measuring the effect of diversification rather than portfolio efficiency evaluation, motivating that return is more variable economic phenomenon than the risk. Portfolios in different size financial markets are formed from different numbers of stocks in order to get the same non-systemic risk elimination effect. In most cases scientists agree about naive portfolio diversification effect. Scientific debates on the measurement of diversification effect of differently-weighted stocks portfolios are still in progress. Therefore, authors of the article solve the scientific problem assessing the possibilities for diversification when portfolios are made of different weight stocks and compare the diversification effect of naive and differently-weighted stocks portfolios. The research is done in Lithuanian Stock Exchange Market and based on daily stock market prices during 2009-2010.

The research methodology is original because the selection of shares to portfolios is carried out under the following criteria in order of priority: 1) the largest negative correlation coefficient values, 2) the quantitative characteristics of the negative correlations with the other stocks in pairs, and 3) stocks of companies from different industry sectors.

The diversification effect is evaluated by three indicators: percentage of diversifiable risk elimination, depending on the number of stocks in portfolio, regressions of standard deviations of portfolios against number and concentration of stocks. The results showed that in all cases greater diversification effect is obtained in naive portfolios.

Keywords: portfolio diversification, diversification effect, number of stocks, concentration index, naive portfolio, differently-weighted portfolio, capitalization.

\section{Introduction}

There are plenty of researches about forming portfolios of stocks. Scientists explore the possibilities of diversification when forming naive and differentlyweighted portfolios; diversification possibilities when forming portfolios of stocks traded in different countries or regional markets; diversification possibilities internationally. Recently scientists increasingly distract attention from the risk-return relationship based strategy and focus it towards the minimum volatility strategy, i.e. direct research from the evaluation of portfolio efficiency to the measurement of portfolio diversification effect. Most of them (Evans \& Archer, 1968; Statman, 1987; Newbould \& Poon, 1993; Sharpe et al., 1997; Tang, 2004; Solnik, 2007; Frahm \& Wiechers, 2011) studied the possibilities of diversification when forming naive portfolios.

Some research results are similar, although depend on the methods used, markets studied and the percentage of non-systemic risk elimination. Tang (2004) summarized the possibilities for diversification of naive portfolios. He stated that naive diversification is a simple but powerful way to reduce portfolio's risk effectively without sacrificing the expected rate of return. His research results showed that for an infinite population of stocks, a portfolio size of 20 is required to eliminate $95 \%$ of the diversifiable risk on average. This result depends neither on the sampling periods, investment horizons nor the markets involved. For a finite population of stocks, the corresponding portfolio size required is smaller, the smaller the population size.

The estimation of diversification effect when forming the differently-weighted stocks portfolios remains a scientific problem. Woerheide and Persson (1993) criticized previous studies for the reason that the amount of assets reflects the degree of portfolio diversification only when the assets weights are equal. They sought to find the indicator which would be suitable for differently-weighted stocks portfolios. One of them is the Herfindahl index.

When the stock markets are huge, one of the problems is to select the appropriate stocks for portfolio. When the stock markets are small portfolios may consist of all its stocks. In any case, there are many combinations of portfolios. Even in the case of 40 companies stocks 780 portfolios can be compiled!

For this reason, the methodology of stocks selection into portfolios is needed. It should allow measuring the diversification effect both of naive portfolios and differently-weighted stocks portfolios.

The object of the research is the stocks' portfolio diversification effect.

The aim of the research is to carry out the analysis of the previous research on portfolio diversification and 
evaluate the diversification effect when forming portfolios in Lithuanian stock exchange market.

To achieve the aim of the research the following tasks are solved:

1) to reason the topicality of scientific researches;

2) to develop the methodology for valuation of diversification effect;

3) to evaluate the diversification effect of portfolios formed in Lithuanian Stock Exchange Market;

4) to compare the diversification effect between naive portfolios and differently-weighted portfolios.

The methods of the research: analysis and synthesis of scientific literature, comparison method, statistical clustering and selection, regression.

\section{Literature Review}

Only little work can be found about the quantitative measurement of the diversifiable effect. Qualitative measurement can be found in Meucci (2009) who describes a portfolio as well-diversified if it is not heavily exposed to individual shocks. However, Markowitz's return - volatility interaction when optimizing portfolio is criticized by both scientists and practitioners. Best and Grauer (1991) studies have shown that the formation of the effective portfolios from risk and return point of view can dramatically change when the prices of portfolio of assets change relatively slightly. The main problem in the application of quantitative methods is the range of assets prices in the future. Traditionally, the expected prices of the assets are determined by using historical stock market prices. The determination of covariance based on historical data is twofold. Firstly, even small portfolio, consisting of 40 shares, has 1482 covariances. This is routine work. It is time consuming, especially when the covariances are determined by using weekly or even daily data. Secondly, Chopra and Ziemba (1993) found that the error in assets pricing is 10 times greater than the error in measurement of assets variance, and about 20 times more expensive than the error in covariance measurement. These results suggest that attention should now be distracted from the strategy based on risk - return relationship to the minimum volatility strategy.

The aim of minimum volatility strategy is to minimize the volatility of portfolio return, regardless of the assessment of portfolio return. Increasing scientists' attention confirms the preference of minimum volatility strategy over the risk - return relationship based strategy (Jagannathan \& Ma, 2003; DeMiguel et. al., 2009; Frahm \& Wiechers, 2011). This is because the benefit of combining assets portfolio in order to minimize the volatility of the return is higher than the losses incurred when moving away from the Markowitz model even if it is assumed that returns on assets are normally distributed.

Some scientists claim that the forecast of return volatility is as much art as science (Sawant, 2001). In addition, it must be in mind that volatility is a hidden process, because it affects the prices of financial instruments and cannot be directly observed (Fouque \& others, 2000). Modern portfolio theory has demonstrated the importance of diversification to investors. While diversification is almost always beneficial in reducing portfolio risk, a commonly asked question is: "How much diversification is enough?"

Evans and Archer (1968) expressed doubts about the size of a portfolio of more than 10 stocks and pointed out the need to perform a marginal analysis when concluding portfolio according to their methodology. Scientists noted that a sharp reduction of risk is achieved by concluding portfolio of 10-20 stocks.

Frahm and Wiechers (2011) stated that diversification effect among the different assets contributes to portfolio performance and even though this perception is old as the hills, diversification is mostly managed by ad-hoc constraints like lower bounds on the number of stocks in a portfolio or other heuristics.

Statman (1987) showed that "a well-diversified portfolio of randomly chosen stocks must include at least 30 stocks for a borrowing investor and 40 stocks for a lending investor. This contradicts the widely accepted notion that the benefits of diversification are virtually exhausted when a portfolio contains approximately 10 stocks. Newbould and Poon (1993) surveyed a number of U.S. investment textbooks and academic studies, and found that the consensus view is that portfolios consisting of 8 to 20 stocks are generally considered well diversified. While Newbould and Poon do not provide a specific number of stocks that would constitute a well-diversified portfolio, they suggest the number would be much greater than 20 . Sharpe et al., (1997) suggest that 30 stocks is the "magic" number 1. According to Byrne and Lee (2000) the growth of the size of portfolio has a direct impact on its risk. Studies prove that the risk of naive portfolio strongly reduces when including 20-40 assets. Further increase of number of assets makes the reduction of risk negligible.

Tang (2004) examined naive (equal weight) diversification and analytically showed that for an infinite population of stocks, a portfolio size of 20 is required to eliminate $95 \%$ of the diversifiable risk on average. However, an addition of 80 stocks (i.e. a size of 100) is required to eliminate an extra $4 \%$ (i.e. $99 \%$ total) of diversifiable risk. This result depends neither on the investment horizons, sampling periods nor the markets involved. But the number of stocks required in portfolio in order to eliminate the same percentage of diversifiable risk differs according to the size of population. For example, in order to eliminate 98 $\%$ of diversifiable risk, 50 stocks are required in 10000 stocks population and 22 - in 40 stocks population.

Frahm and Wiechers (2011) empirical research was carried out on monthly return data for the S\&P500 constituents, with a return history spanning the last five decades. When measuring the diversification of naively allocated 40-asset portfolios, the average degree of diversification barely exceeds $60 \%$. This result indicates that for the mutual fund manager as well as for the private investor well-founded selection of assets indeed leads to better portfolio diversification than naive allocation does.

The number of stocks is a well-known measurement of portfolio diversification. The risk of portfolio decreases with the increase of financial instruments in it (Frahm \& Wiechers, 2011). When increasing the number of stocks in portfolio, total risk will decrease gradually until you achieve a degree of risk that they will not be able to reduce more, regardless the additional stocks added to portfolio. 
The increasing diversification of portfolio gradually eliminates non-systematic risk, leaving only the systematic or market-driven risk. However, too high diversification often dispels the risk, causes more operating costs and reduces return. For this reason the efficiency of portfolio decreases.

Solnik (2007), after examining the U.S. stock market, indicates that the sufficient number of stocks in portfolio in the U.S. stock market is 20 . The results of this scientist's previous researches are far different. After performing the six years weekly return analysis in eight different countries Solnik (1974) indicates that the benefit of diversification is different in individual stock markets i.e. the elimination of non-systemic risk requires a different number of stocks. These results are contrary to the statement of Tang (2004) that the diversification effect does not depend on the market involved. Zulkifli et al., (2010) after examination of the Malaysian stock market concluded that the benefit of diversification can be fully achieved by investing in portfolio of 15 stocks. Well-diversified portfolio contains weakly related assets, when the degree of correlation between them is low and the revenue because of diversification is maximized.

The most elementary approach to measure the diversification of a portfolio of risky assets is to count the number of stocks. Numerous studies (Evans \& Archer, 1968; Fisher \& Lorie, 1970) have pursued this methodology. Evans \& Archer (1968) built equally-weighted d-asset portfolios comprising randomly chosen assets from S\&P500 index for the year 1958. They concluded that "raise doubts concerning the economic justification of increasing portfolio sizes beyond 10 or so stocks, and indicate the need for analysts and private investor alike to include some form of marginal analysis in their portfolio selection models".

Fundamental contradictions are caused by the scientific debate on the weights when creating stock portfolios, in order to maximize the benefit of diversification. Assets allocation is both a process and methodology intended to help decision-makers to achieve the investment purposes by dividing limited resources among different alternatives (Coyne, 2008). All quantitative assets allocation techniques are based on various restrictions.

Other approach in assessing the degree of portfolio diversification arises from information theory. Woerheide and Persson (1993) in portfolio theory used information theory and the indicators of economic concentration in order to assess the concentration of individual asset's weight. From their point of view when measuring portfolio diversification asset's weight depends not only on the number of assets, but also on the weight of investor's assets. Scientists mentioned have criticized previous researches that the number of assets reflects the degree of portfolio diversification only when the weights of assets are equal. They sought to find the target, which is suitable for the different weights of the total portfolio of assets. They sought to find the indicator which is suitable for portfolios concluded of different weighted assets. The researchers investigated 5 predetermined measures, which are called Diversification Indices (DI). These include the complements of the Herfindahl and the Rosenbluth indices, respectively, the entropy measure as well as two other measures (Woerheide \& Persson, 1993). They found that among the 5 indices of diversification the highest explanatory power with an $\mathrm{R}^{2}$ of 0.548 has $\mathrm{CHI}$. CHI index, inverse to Herfindahl Hirschman Index (HHI).

Other studies that incorporate information-theoretical approach are Bouchaud et al (1997) and Bera and Park (2008), although these work are directed more onto portfolio construction itself. Nevertheless, both works deal with a certain level of diversification during the construction process of the optimal portfolio.

Burnside et al., (2004) empirically proved that the best results of diversification are obtained when the weights of assets are evaluated in terms of capitalization size. This argument is valid, if the market index is dominated by very high and relatively low capitalization issuers.

Hight (2009) defined the diversification effect as a reduction in portfolio risk created by imperfect correlations between asset return pairs. He stated that portfolio risk is not merely a function of imperfect correlations; allocation and risk imposed by individual asset returns also determine portfolio risk. The proposed ratio as a measure of diversification effect shows how many of total risk can be diversified away by forming portfolios. Using this ratio both naive and different weight portfolios diversification can be measured.

\section{Research Methodology}

In the variance-covariance method it is presumed that the estimated parameters - covariances and standard deviations - don't change over time, but this is often denied by empirical results, for example, Andersen et al (2004). Despite of shortcomings mentioned, variancecovariance method is simple, intuitive, easily understood and explained. It is also efficient in terms of resources used. According to Dzikevicius (2005), variancecovariance method is recommended to be applied when the changes of market variables are distributed according to normal probability distribution. This method can also be used when the changes of market variables are not distributed according to normal probability distribution, if their number is large enough and they can be considered independently. This method is easy to calculate how much risk an individual asset adds to the overall portfolio risk.

Variance and standard deviation when analyzing historical data are calculated using these formulas:

$$
\sigma^{2}=\sum_{i=1}^{n} \frac{\left(r_{i}-\bar{r}\right)^{2}}{n-1}
$$

here: $\mathrm{r}_{\mathrm{i}}$ - return of stock;

$\bar{r}$ - average return of stock;

$\mathrm{n}$ - number of samples.

$$
\sigma=\sqrt{\sigma^{2}}
$$

Daily standard deviation is calculated by using daily stock returns. It must be converted to annual by the following formula:

$$
\sigma=\sigma_{d} \sqrt{n}
$$

here: $\sigma-$ annual standard deviation of return; 
$\sigma_{\mathrm{d}}$ - daily standard deviation of return;

$\mathrm{n}$ - number of trading days per year.

When calculating the standard deviation of return of stocks, firstly deviation of returns of years 2009 and 2010 are calculated, when they are summed and divided by 2 (to calculate arithmetic mean).

Portfolio risk is caused by covariance and correlation. Each of the stocks has a certain return of particular period and a tendency to vary during the year. These different returns of stocks are not completely independent. Sometimes they have a tendency to "move" in one direction (coefficient is positive), and in some cases, reversed (coefficient is negative). In case of zero covariance, returns of two assets are independent. While having historical data on return of stocks and average returns, the covariance is calculated as follows:

$$
\operatorname{Cov}\left(r_{i} r_{j}\right)=\frac{\sum_{i=1, j=1}^{n}\left(r_{i}-\overline{r_{i}}\right)\left(r_{j}-\overline{r_{j}}\right)}{n-1}
$$

The covariance of financial instrument with itself is the standard deviation of the instrument. As the number of financial instruments in portfolio increase, the number of covariances $\mathrm{S}$ increases too:

$$
S=\frac{n(n-1)}{2}
$$

In order to calculate the covariance effect between financial assets, it is necessary to evaluate the correlation coefficient between each pair of stock $i$ and stock $j$. The correlation coefficient $r_{i j}$ is a statistical measure which evaluates the strength of relation between two assets returns. Correlation coefficient varies in range of $[-1,1]$ and is calculated by the following formula:

$$
\operatorname{Corr}\left(r_{i} r_{j}\right)=\frac{\operatorname{Cov}\left(r_{i} r_{j}\right)}{\sigma_{i} \sigma_{j}}
$$

In case of direct relation, both of financial assets returns vary to the same direction while in case of inverse relationship when one of financial assets return increases, the other's decreases. In case of zero correlation there is no relation between returns of two financial assets.

The calculation of varying covariance and covariance matrix between all the financial instruments returns are extremely important for evaluation of financial instruments, solution of portfolio selection task. Therefore it is concluded that while forming portfolio and trying to diversify, it is appropriate to choose negatively correlated assets.

The risk of portfolio is determined by two characteristics: weighted risk of individual instruments (standard deviations) and weighted relationships between the instruments (covariance). Statistical measure - the standard deviation of portfolio is calculated by using the formula:

$$
\sigma_{p}=\sqrt{\sum_{i=1}^{n} w_{i}^{2} \sigma_{i}^{2}+\sum_{i=1}^{n} \sum_{j=1}^{n} w_{i} w_{j} \sigma_{i} \sigma_{j} \operatorname{Corr}\left(r_{i} r_{j}\right)}
$$

here: $\mathrm{w}$ - weights of stocks in portfolio.
The risk of portfolio is determined by individual financial assets variance, covariance between the assets and the weight of individual asset in invested sum of money. The more financial instruments are included into portfolio, the smaller is the weight of individual financial instrument's risk, and the bigger is the influence of covariance. The larger $n$ becomes, the less is the variability (which is getting close to zero). Therefore, when portfolio consists of many instruments, the second part of the equation influences the risk mostly, and the risk of portfolio can be calculated only by this equation:

$$
\sigma_{p}=\sqrt{\sum_{i=1}^{n} \sum_{j=1}^{n} w_{i} w_{j} \sigma_{i} \sigma_{j} \operatorname{Corr}\left(r_{i} r_{j}\right)}
$$

The first part of portfolio standard deviation formula (7) shows non-systematic (diversified) risk, and the second systemic (non-diversified) risk.

Tang (2004) argues that with a finite number of stocks on the market, the part of maximum potentially diversifiable risk is determined as follows:

$$
\sigma_{\text {div }}=\frac{(\mathrm{n}-1) / \mathrm{n}}{(\mathrm{N}-1) / \mathrm{N}}
$$

here: $\sigma_{\mathrm{div}}-$ proportion of diversifiable risk;

$\mathrm{n}$ - number of stocks in portfolio;

$\mathrm{N}-$ total number of stocks in a market.

Scientist presents a number of conclusions: 1) when forming naive portfolio, the power of diversification is inversely proportional to the size $\mathrm{n}$ of the portfolio: 2 stocks are required to eliminate 50 percent of risk, 10 stocks - 90 percent and 20 stocks - to eliminate 95 percent of risk; 2) the efficiency of naive portfolios diversification does not depend on the sample period, nor on the investment horizon or the markets explored; 3) a part of non-systemic risk cannot be completely eliminated, except for a case of the market with infinite number of stocks.

The number of stocks can be used to measure diversification effect but only when portfolio consists of equal weighted stocks. Firstly, in such case the number of stocks is the best indicator because in large markets portfolios are concluded of randomly chosen ones. Thus, a part of the stocks will never be included into investigation of portfolio diversification effect. Secondly, a set of weights and the combinations of stocks in portfolio from practical point of view are infinite. When concluding portfolios of chosen stocks rather than the general population, the different weights of shares cannot be determined because the number of combinations of stocks is immeasurable.

When investigating opportunities for diversification in the Lithuanian stock exchange market, where the number of stocks is 40, portfolio may include all the stocks. Therefore the diversification effect can be measured by the number of stocks even if portfolio includes different weighted stocks according to clearly defined selection method.

In case of different weighted stocks in a portfolio, the weights of stocks are determined by their capitalization. This is based on the statement of Burnside et al (2004) that the best results of diversification are obtained when the weights of assets are evaluated in terms of capitalization 
size. This statement is valid if in the market index are dominated the issuers with very high and relatively low capitalization. It is particularly suitable for the Lithuanian stock exchange market, where the capitalizations of issuers in total capitalization are very different.

Regardless of the number of stocks in a portfolio, the weight of each stock is determined by the total capitalization of stocks included into portfolio:

$$
w=\frac{C_{s}}{C_{t}}
$$

here: $\mathrm{w}$ - stock weight in a portfolio;

$\mathrm{C}_{\mathrm{s}}$ - capitalization of stock in a portfolio;

$\mathrm{C}_{\mathrm{d}}$ - total capitalization of stocks in a portfolio.

Stock selection into both naive and different weight portfolio, consisting of 2-39 stocks, is carried out in accordance with the following criteria in order of priority: 1) the largest negative values of correlation coefficients, 2) the quantitative characteristics of the negative correlations with the other pairs of stocks, and 3) stocks of companies belonging to different industry sectors. The novelty of the research is that portfolios are formed by three criteria mentioned above, so the number of portfolios will be equal to the number of stocks in Lithuanian stock exchange market minus 1 . It will allow evaluating the suitability of these criteria to conclude diversified portfolio and portfolio diversification effects in case of both naive and differentlyweighted portfolios. It should be noted that this selection process doesn't fully ensure the decrease of diversified risk when increasing the number of stocks. However a hypothesis is raised that the results of the study will correspond with Tang (2004) results when concluding naive portfolios and exactly how many of diversification effect can be measured by the number of stocks in differently-weighted portfolios.

The terms „diversification“ (Markowitz, 1952) and „diversification effect" (Perold et al., 2004,) refer to the relationship between correlations and portfolio risk. When resources are allocated to assets whose returns have imperfect correlations, the result is diversification effect (DE) (Hight, 2009). Furthermore, risk reduction can occur without comprising returns, thereby potentially increasing risk-adjusted returns (Cooley et. al., 2003; Gibson, 2004).

One of the DE metrics in the study of Cheng and Roulac (2007) was a ratio with portfolio standard deviation in the numerator and the allocation-only weighted portfolio standards deviation in the denominator. Portfolio standard deviation in the numerator was calculated using the form expressed in Equation 7. The allocation-only weighted portfolio standards deviation form is identical to portfolio standard deviation form, except that the correlation coefficient argument is forced to equal +1 . Cheng and Roulac (2007) applied this ratio in real estate portfolios, while Choueifaty and Coignard (2008) applied a similar ratio to analysis of DE in financial asset portfolios.

Cheng and Roulac (2007) and Choueifaty and Coignard (2008) DE metrics share a fundamental idea: DE resides in the difference between the allocation-only weighted standard deviation and the standard deviation weighted by both correlation and allocation.
The Equation 11, expressed by Hight (2009), assumes the fundamental idea expressed in the earlier studies. This form yields a DE metric that always assumes a value greater than zero and less than +1 . Also, when the value is large, it indicates high $\mathrm{DE}$ and small values indicate low DE:

$$
D E=1-\frac{\sigma_{p}}{\sigma_{a}}
$$

here: DE - diversification effect;

$\sigma_{\mathrm{p}}-$ portfolio standard deviation weighted by allocations and the correlations between returns of individual assets;

$\sigma_{\mathrm{a}}-$ allocation-only weighted portfolio standard deviation.

The form of allocation-only weighted portfolio standard deviation is expressed in Equation 12:

$$
\sigma_{\mathrm{a}}=\sum_{\mathrm{i}=1}^{\mathrm{n}} \mathrm{w}_{\mathrm{i}} \sigma_{\mathrm{i}}
$$

here: $\sigma_{\mathrm{a}}$ - allocation-only weighted portfolio standard deviation.

$\mathrm{W}_{\mathrm{i}}$ - the allocation of weight of each asset;

$\sigma_{I}-$ the standard deviation of each asset's return.

The proposed ratio as a measure of diversification effect shows how many of the total risk can be diversified away by forming portfolios. Previous researches, as mentioned in the literature review, are concerned with the elimination of the diversifiable risk. So, calculating the DE, non-diversifiable risk should be excluded. Nondiversifiable risk is estimated as the lowest standard deviation between all formed stocks portfolios, and the DE is calculated as follows:

$$
D E=1-\frac{\sigma_{p}-\sigma_{p}(\min )}{\sigma_{a}-\sigma_{p}(\min )}
$$

here: $\sigma_{\mathrm{p}}(\mathrm{min})$ - the lowest standard deviation between all formed stocks portfolios.

Another way to measure the diversification of risky portfolio of assets is to count the components related to portfolio and to identify the dependence of standard deviation on the number of stocks (Frahm 2011). This methodology was used in numerous studies, including two major: Evans and Archer (1968), Fisher and Lorie (1970). Evans and Archer (1968) concluded portfolios of equal weight $\mathrm{d}$ assets, including randomly selected assets from the S\&P500 index in 1958. Portfolios were made of 1-40 stocks (a total of 60 replays), and standard deviations of all portfolios were calculated. Then the dependence of portfolios standard deviations on the number of their assets was determined i.e. the factor, expressed as $1 / \mathrm{d}$ :

$$
\bar{\sigma}_{d}^{2}=\alpha+\beta \frac{1}{d}+\varepsilon
$$

Studies have shown that the variance of naive portfolio's return decreased with increasing number of its components. Variables $\mathrm{d}$ and $\mathrm{n}$ are equal when portfolios are concluded of all the stocks in a particular stock market (author's note). 
Vilija Alekneviciene, Egle Alekneviciute, Rasa Rinkeviciene. Portfolio Size and Diversification Effect in Lithuanian...

Woerheide and Persson (1993) criticized previous researches on the statement that the number of assets reflects the degree of portfolio diversification only when the weights of assets are equal. They sought to find an indicator which is suitable for portfolios concluded of different weight assets. Scientists tested five indicators in order to assess diversification. One of them was CHI index, inverse to Herfindahl Hirschman Index (HHI):

$$
C H I(w)=1-\sum_{i=1}^{d} w_{i}^{2}
$$

As already mentioned, CHI (w) is inverse to HHI. When investigating dependence between the risk of portfolios of stocks and HHI, it must be positive, because with the increase of the concentration of stocks in portfolio, standard deviations need to increase too. To examine the dependence of portfolios standard deviations on concentration the authors will use Herfindahl Hirschman Index (HHI).

\section{Research Results}

To evaluate diversification effect the authors use the ratios, mentioned in research methodology:

- the percent of diversified risk elimination, depending on the number of stocks in portfolio;

- portfolio risk dependence on stock concentration index;

- portfolio risk dependence on the number of stocks in portfolio.

The diversification effect according to the number of stocks is presented in the Table 1. Two stocks portfolio consists of corporate group "Alita" (AGP1L) and "Dvarcioniu keramika" (DKR1L), three stocks portfolio consists of corporate group "Alita" (AGP1L), "Dvarcioniu keramika" (DKR1L) and "Lifosa" (LFO1L), and etc.

Diversification Effect According to the Number of Stocks in Portfolio

Table 1

\begin{tabular}{|c|c|c|c|}
\hline Number of stocks in portfolio & $\begin{array}{l}\text { Abbreviation of title of joint- } \\
\text { stock company }\end{array}$ & $\begin{array}{l}\text { Diversification effect of naive } \\
\text { portfolios }\end{array}$ & $\begin{array}{c}\text { Diversification effect of } \\
\text { differently-weighted portfolios by } \\
\text { capitalization }\end{array}$ \\
\hline 2 & AGP1L+DKR1L & 39 & 36 \\
\hline 3 & + LFO1L & 53 & 10 \\
\hline 4 & + GUB1L & 62 & 14 \\
\hline 5 & + +UTR1L & 67 & 21 \\
\hline 6 & + VDG1L & 71 & 32 \\
\hline 7 & + SAN1L & 76 & 58 \\
\hline 8 & + VBL1L & 80 & 66 \\
\hline 9 & +STU1L & 83 & 72 \\
\hline 10 & + KNR1L & 85 & 78 \\
\hline 11 & + LJL1L & 88 & 79 \\
\hline 12 & + SNG1L & 88 & 80 \\
\hline 13 & + VST1L & 90 & 80 \\
\hline 14 & + KBL1L & 92 & 80 \\
\hline 15 & + RSU1L & 93 & 83 \\
\hline 16 & + GRG1L & 94 & 84 \\
\hline 17 & + KNF1L & 96 & 92 \\
\hline 18 & + LNS1L & 96 & 92 \\
\hline 19 & +LEL1L & 97 & 95 \\
\hline 20 & + ANK1L & 98 & 96 \\
\hline 21 & + UKB1L & 98 & 96 \\
\hline 22 & + +ZMP1L & 98 & 97 \\
\hline 23 & +VLP1L & 100 & 97 \\
\hline 24 & + LNA1L & 99 & 99 \\
\hline 25 & $+\mathrm{AVG} 1 \mathrm{~L}$ & 99 & 99 \\
\hline 26 & + PZV1L & 99 & 100 \\
\hline 27 & + RST1L & 99 & 99 \\
\hline 28 & + SRS2L & 100 & 99 \\
\hline 29 & +LEN1L & 100 & 96 \\
\hline 30 & + PTR1L & 99 & 96 \\
\hline 31 & + LLK1L & 100 & 96 \\
\hline 32 & + IVL1L & 99 & 96 \\
\hline 33 & + SRS1L & 98 & 95 \\
\hline 34 & + ALT1L & 97 & 95 \\
\hline 35 & + CTS1L & 97 & 95 \\
\hline 36 & + TEO1L & 98 & 100 \\
\hline 37 & + APG1L & 97 & 100 \\
\hline 38 & $+\mathrm{LDJ1L}$ & 97 & 100 \\
\hline 39 & + SAB1L & 97 & 100 \\
\hline
\end{tabular}

Diversification effect shows what percentage of nonsystemic risk can be eliminated by changing the number of stocks in portfolio. Forming naive portfolios the diversification effect increases from $39 \%$ to $98 \%$, while the selection of stocks in portfolio according to the criteria in order of priority (the highest negative values of correlation coefficient; the quantitative characteristics of negative correlations with the other pairs of stocks; the stocks of companies from different industry sectors) worked out only to a portfolio consisting of 22 stocks. From portfolios, 
consisted of more than 22 stocks, the selection of stocks didn't work out, because the diversification effect went up and down. So it follows that forming naive portfolios and adjusting the authors' methodology for stock selection the increase of the number of stocks leads to increasing part of eliminated non-systemic risk. The studies on diversification effect confirmed Tang (2004) statement that the power of diversification is inversely proportional to the size of portfolio. Attention must be paid to the fact that the methodology of portfolios formation by Tang (2004) is different: stocks are selected randomly, and all the possible combinations of portfolios are concluded according to the number of stocks in them. For this reason, the diversification effect determined by the authors is a bit smaller, but it should be noted that the results of Tang
(2004) and the authors are the same when portfolio consists of 22 stocks, because $98 \%$ of non-systemic risk is eliminated.

When forming differently-weighted stock portfolios by capitalization, there is the same pattern as when forming naive portfolios. With the increase of the number of stocks, gradually increase the part of diversified risk from 36 percent to 99 percent. Selection of stocks into portfolio according to the criteria mentioned has proved only to a portfolio of up to 25 stocks. From portfolios of more than 25 stocks the selection didn't work, because the diversification effect went up and down. The results showed that the diversification effect, when forming differently-weighted stock portfolios, in all cases is smaller than concluding naive portfolios (Figure 1).

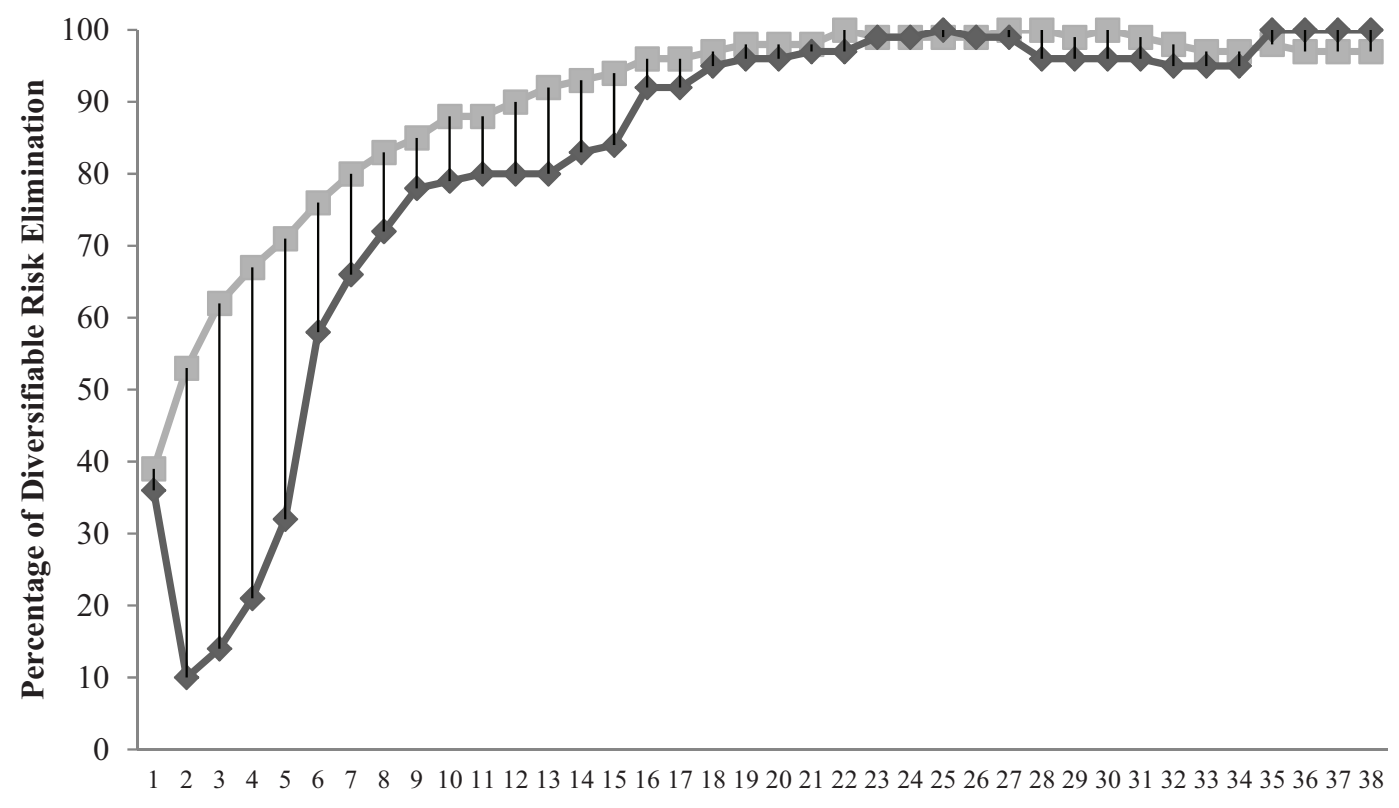

Number of Stocks

$\because$-Naive Portfolios $\quad$ Differently-weighted Portfolios by Capitalization

Figure 1. Percentage of Diversifiable Risk Elimination in Naive and Differently-weighted Portfolios by Capitalization

The major difference between diversification effects of naive and differently weighted portfolios is when they consist of smaller number of stocks. The bigger the portfolios the lower is the difference between diversification effects.

After evaluating portfolios standard deviations dependence on the concentration of stocks in them, it was found that this dependence is stronger of equally- weighted portfolios. The statistics of regression models, made for the stock portfolios risk dependence on the concentration are presented in Table 1. The standard deviation of equallyweighted portfolios is even $98.9 \%$ caused by the concentration of stocks, and the linear regression equation takes the following expression:

$$
\sigma_{p}=13.34+115.82 H H I
$$

This linear regression equation shows a direct dependence of portfolios standard deviations on the stock concentration. When the Herfindahl-Hirschman Index (HHI) moves to 1, portfolio standard deviation increases. The maximum possible value of $\mathrm{HHI}$, when a portfolio consists of two stocks in equal parts is 0.5 . Then the average standard deviation of portfolio is $71.2 \%$.

The standard deviation of differently-weighted stocks portfolios is caused by the concentration only $45.5 \%$, while the linear regression equation takes the following expression:

$$
\sigma_{p}=17.52+24.96 H H I
$$

In this case, there is also a direct dependence of portfolios standard deviations on the concentration of stocks in them. Noting that the coefficient of determination is small, possible non-linear regression equations were created. The results showed that the highest coefficient of determination $\left(\mathrm{R}^{2}=0.680\right)$ was in power regression equation, so it is statistically most significant: 
Vilija Alekneviciene, Egle Alekneviciute, Rasa Rinkeviciene. Portfolio Size and Diversification Effect in Lithuanian ...

$$
\sigma_{p}=37.02(H H I)^{0,28}
$$

From the statistics in Table 2 it appears that all the models are statistically significant.

Table 2

The Statistics of Regression Models for the Stock Portfolios Risk Dependence on the Concentration

\begin{tabular}{|l|c|c|}
\hline \multicolumn{1}{|c|}{ Regression model } & $\mathbf{R}^{2}$ & $\mathbf{p}$-value $(\boldsymbol{\alpha}=\mathbf{0 . 0 5})$ \\
\hline Linear for naive portfolios & 0.989 & 0.000 \\
\hline $\begin{array}{l}\text { Linear for differently-weighted } \\
\text { portfolios }\end{array}$ & 0.455 & 0.000 \\
\hline $\begin{array}{l}\text { Power for differently-weighted } \\
\text { portfolios }\end{array}$ & 0.680 & 0.000 \\
\hline
\end{tabular}

As was mentioned earlier, Woerheide and Persson (1993) found that among the 5 indices of diversification the highest explanatory power with an $\mathrm{R}^{2}$ of 0.548 has CHI. Our research results showed that $\mathrm{R}^{2}$ is 0.989 of naive portfolios and $\mathrm{R}^{2}$ is 0.455 of differently-weighted portfolios in the linear relationship.

The assessment of portfolio standard deviation dependence on the number of stocks revealed that linear dependences are very similar. The statistics of regression models are presented in Table 3. The standard deviation of naive portfolios is caused by the number of stocks 47.9 percent, and the linear regression equation takes the following expression:

$$
\sigma_{p}=37.53-0.70 \mathrm{~N}
$$

Table 3

The Statistics of Regression Models for the Stock Portfolios Risk Dependence on the Number of Stocks

\begin{tabular}{|l|c|c|}
\hline \multicolumn{1}{|c|}{ Regression model } & $\mathbf{R}^{\mathbf{2}}$ & p-value $(\boldsymbol{\alpha}=\mathbf{0 . 0 5})$ \\
\hline Linear for naive portfolios & 0.479 & 0.000 \\
\hline $\begin{array}{l}\text { Linear for differently-weighted } \\
\text { portfolios }\end{array}$ & 0.395 & 0.000 \\
\hline Inverse for naive portfolios & 0.989 & 0.000 \\
\hline $\begin{array}{l}\text { Inverse for differently- } \\
\text { weighted portfolios }\end{array}$ & 0.917 & 0.000 \\
\hline
\end{tabular}

The standard deviation of differently-weighted stocks portfolios is caused by the number of stocks slightly less $(39.5 \%)$, and the linear regression equation takes the following expression:

$$
\sigma_{p}=34.88-0.54 \mathrm{~N}
$$

Noting that the coefficients of determination of linear regression equations are small, possible non-linear regression equations were created. The results showed that the highest coefficient of determination $\left(\mathrm{R}^{2}=0.989\right)$ for naive portfolios had inverse regression equation, so it is statistically most significant:

$$
\sigma_{p}=13.34+(115.81 / N)
$$

After adapting the regression equation for portfolio, consisting of 2 equal weights stocks, its standard deviation was $71.2 \%$. With the increase of number of stocks the standard deviation of portfolio decreased.

For differently-weighted portfolios the highest coefficient of determination $\left(\mathrm{R}^{2}=0.917\right)$ also is in the inverse regression equation and it is statistically most significant:

$$
\sigma_{p}=15.75+(94.80 / N)
$$

From the statistics in Table 3 it is seen that all models are statistically significant.

\section{Conclusions and Discussions}

Scientific debates on the measurement of the diversification effect of differently-weighted stocks portfolios are still in progress. The research problem is how to measure the diversification effect of differentlyweighted portfolios, and does the diversification effect depends on the weights of stocks in portfolios.

The research is done in Lithuanian Stock Exchange Market and based on daily stock market prices during 2009-2010. The authors formed both naive portfolios and differently-weighted stocks portfolios by capitalization using three stocks' selection criterions by priority: 1) highest negative correlations between the pairs of stocks; 2) quantitative negative correlations characteristics with other pairs of stocks; 3) stocks of companies from the different industry sectors. The diversification effect was measured by the number of stocks, regressions of standard deviations of portfolios against number and concentration of stocks.

The research results showed that forming naive portfolios, the diversification effect is slightly larger than forming differently-weighted portfolios by capitalization. In order to eliminate $98 \%$ of diversifiable risk, naive portfolio from 22 stocks should be formed. These research results confirmed Tang (2004) research results. However, in general, the diversification effect is slightly less comparable with diversification effect estimated by Tang. The main reason is the different methodics of stocks selection in portfolios. Forming differently-weighted portfolios by capitalization from 22 stocks, $97 \%$ of diversifiable risk can be eliminated. The limitation of chosen methodics is that the selection is proper till 22 and 25 stocks (naive and differently-weighted portfolios accordingly).

The research results also showed that the major difference between diversification effects of naive and differently weighted portfolios is when they consist of smaller number of stocks. The bigger the portfolios the lower is the difference between diversification effects.

The research results on regression of standard deviations of portfolios against concentration of stocks showed that $R^{2}$ is 0.989 of naive portfolios and $R^{2}$ is 0.455 of differently-weighted portfolios in the linear relationship. Woerheide and Persson (1993) found that among the 5 indices of diversification the highest explanatory power with an $\mathrm{R}^{2}$ of 0.548 has CHI. The dependence of standard deviations of portfolios on number of shares is very similar: under linear relationship $\mathrm{R}^{2}$ is 0.479 and 0.395 (naive and differently-weighted portfolios accordingly). The regressions of standard deviations of portfolios against number of stocks under inverse regression equation have rather higher $\mathrm{R}^{2}$ : 0.989 of naive portfolios and 0.917 of differently-weighted portfolios. 


\section{References}

Andersen, T. G., Bollerslev, T., Christoffersen, P. F., \& Diebold, F. X. (2004). Practical Volatility and Correlation Modeling for Financial Market Risk Management Draft of October 14, 2004 for Mark Carey and Rene Stulz. Risk of Financial Institutions, NBER. Available from Internet: http://www.gloriamundi.org

Bera, A. K., \& Park, S. Y. (2008). Optimal Portfolio Diversification using Maximum Entropy. Econometric Reviews, 27(4-6), 484-512. http://dx.doi.org/10.1080/07474930801960394

Best, R. W., \& Grauer, R. R. (1991). On the Sensitivity of Mean-Variance-Efficient Portfolios to Changes in Asset Means: Some Analytical and Computational Results. The Review of Financial Studies, 4(2), 315-342. http://dx.doi.org/10.1093/rfs/4.2.315

Bouchaud, J. P., Potters, M., \& Aguilar, J. P. (1997). Missing Information and Asset Allocation. Available from Internet: http://econpapers.repec.org?RePEc:sfi:sfiwpa:500045

Burnside, D. J., Chambers, D. R., \& Zdanowicz, J. S. (2004). How Many Stocks Do You Need to be Diversified? AAII journal, 16-19.

Byrne, J. P., \& Lee, S. (2000). Risk Reduction and Real Estate Portfolio Size. Presented at the Sixth PRRES Conference Sydney, Australia. Available from Internet: http://thankssjerseys.org/Papers/Lee_Risk_Reduction_and_Real_Estate_ Portfolio_Size.pdf

Cheng, P., \& Roulac, S.E. (2007). Measuring the Effectiveness of Geographical Diversification. Journal of Real Estate Management, 13(1), 29-44.

Chopra, V. K., \& Ziemba, W. T. (1993). The Effect of Errors in Mean, Variance and Covariance Estimates on optimal portfolio Choise. Journal of Portfolio Management, 19, 6-11. http://dx.doi.org/10.3905/jpm.1993.409440

Choueifaty, Y., \& Coignard, Y. (2008). Toward Maximum Diversification. Journal of Portfolio Management, 35(1) 40-51. http://dx.doi.org/10.3905/JPM.2008.35.1.40

Cooley, P. L., Hubbard, C. M., \& Walz, D. T. (2003). Does International Diversification Effect Increase the Sustainable Withdrawal Rates from Retirement Portfolios? Journal of Financial Planning (January), 74-80.

Coyne, T. (2008). Asset Allocation Methodologies. QFinance. Available from Internet: http://www.qfinance.com/ contentFiles/QF02/g1xtn5q6/12/1/asset-allocation-methodologies.pdf

DeMiguel, V., Garlappi, L., \& Uppal, R. (2009). Optimal Versus Naive Diversification: How Inefficient is the 1/N Portfolio Strategy? The Review of Financial Studies, 22(5), 1915-1953. http://dx.doi.org/10.1093/rfs/hhm075

Dzikevicius, A. (2005). Prekybinio portfelio rizikos valdymas banke. Daktaro disertacija. Socialiniai mokslai, ekonomika. VGTU, Vilnius. Priega per interneta: http://vddb.library.lt/fedora/get/LT-eLABa-0001:E.02 2006 D _20060404_ 135845-50706/DS.005.0.02.ETD

Evans, J., \& Arsher, S. (1968). Diversification and the Reduction of Dispersion. Journal of Finance, 23(5), 761-767.

Fisher, L., \& Lorie, J. H. (1970). Some Studies of Variability of Returns on Investments in Common Stocks. The Journal of Business, 43(2), 99-134. http://dx.doi.org/10.1086/295259

Fouque, J. P., Papanicolaou, K., \& Sircar, R. (2000). Derivatives in Financial Markets with Stochastic Volatility Cambridge: Cambridge University Press.

Frahm, G., \& Wiechers, C. (2011). On the Diversification of Portfolios of Risky Assets. Seminar of Economic and Social Statistic University of Cologne, No. 1/11.

Gibson, R. C. (2004). The Rewards of Multiple-Asset-Class Investing. Journal of Financial Planning, 17(7), 58-71.

Hight, G. (2009). A New Way to Look at Correlations: The Incremental Diversification Effect Measure. Journal of Indexes, 44-49.

Jagannathan, R., \& Tongshu, M. (2003). Risk Reduction in Large Portfolios: Why Imposing the Wrong Constraints Helps. The Journal of Finance. 58(4), 1651-1684. http://dx.doi.org/10.1111/1540-6261.00580

Meucci, A. (2009). Managing Diversification. Risk, 22(55), 74-79.

Newbould, G. D., \& Poon, P. S. (1993). The Minimum Number of Stocks Needed for Diversification. Financial Practice and Education, 3, 85-87.

Sawant, S. (2001). Forecasting Volatility: A Literature Survey, Article 1, ICICI Ltd.

Sharpe, W. F., Alexander, G. J. Bailey, J. V., \& Fowler, D. J. (1997). Investments. Second Canadian Edition, Scarborough, Ontario, Prentice Hall Canada Incorporated.

Statman, M. (1987). How Many Stocks Make a Diversified Portfolio? Journal of Financial and Quantitative Analysis, 22, 353-363. http://dx.doi.org/10.2307/2330969

Tang, G. Y. N. (2004). How Efficient is Naive Portfolio Diversification? An Educational Note. The International Journal of Management Science, 32, 155-160.

Woerheide, W., \& Persson, D. (1993). An Index of Portfolio Diversification. Financial Services Review, 2(2), 73-85. http://dx.doi.org/10.1016/1057-0810(92)90003-U 
Vilija Alekneviciene, Egle Alekneviciute, Rasa Rinkeviciene. Portfolio Size and Diversification Effect in Lithuanian ...

Vilija Aleknevičienè, Egle Aleknevičiūtè, Rasa Rinkevičienė

Portfelio dydis ir diversifikavimo efektas Lietuvos akcijų rinkoje

Santrauka

Pastaruoju metu mokslininkai vis daugiau dèmesio skiria diversifikavimo efektui išmatuoti, o ne portfelių efektyvumui vertinti, motyvuodami tuo, kad pelningumas yra stipriau kintantis ekonominis reiškinys nei rizika. Best ir Grauer (1991) atlikti tyrimai parodė, kad efektyviu portfeliu formavimas rizikos ir pelningumo požiūriu gali dramatiškai pasikeisti, palyginti nežymiai pasikeitus ì portfeli įtraukto turto kainoms. Chopra ir Ziemba (1993) nustatė, kad turto kainų nustatymo paklaida yra 10 kartų didesnè nei variacijų nustatymo, ir apie 20 kartų brangesnè nei kovariacijų nustatymo paklaida. Šie tyrimų rezultatai rodo, kad šiandien demesị reikia atitraukti nuo rizikos ir pelningumo ryšiu grindžiamos strategijos, link minimalaus kintamumo strategijos.

Norint gauti tą patị nesisteminès rizikos eliminavimo efektą skirtingo dydžio finansų rinkose, akcijų portfeliai sudaromi iš skirtingo akcijų skaičiaus. Dèl diversifikavimo galimybių, sudarant portfelius iš akciju lygiais svoriais, pastaruoju metu mokslininkai beveik vienareikšmiškai sutinka. Dauguma ju (Evans ir Archer, 1968; Statman, 1987; Newbould ir Poon, 1993; Sharpe, Alexander, Bailey ir Fowler, 1997; Tang, 2004; Solnik, 2007; Frahm ir Wiechers, 2011) būtent ir tyrè diversifikavimo galimybes, sudarant portfelius iš akcijų lygiais svoriais. Mokslininkų gauti tyrimų rezultatai yra panašūs, nors ir skiriasi, priklausomai nuo taikytų metodų, tirtų rinkų ir gauto nesisteminès rizikos eliminavimo procento. Tang (2004) savo tyrimais apibendrino diversifikavimo galimybes, kai portfeliai sudaromi iš akciju lygiais svoriais. Mokslininko gauti tyrimo rezultatai parodè, kad esant begaliniam akciju skaičiui ir siekiant vidutiniškai eliminuoti $95 \%$ diversifikuojamos rizikos, reikia suformuoti portfeli iš 20 akcijų. Rezultatas nepriklauso nei nuo periodo, nei nuo investavimo horizonto, nei nuo tiriamų rinkų. Esant baigtiniam akcijų skaičiui, diversifikavimo efektas priklauso nuo rinkoje esančių akcijų skaičiaus: kuo jis mažesnis, tuo mažesnis turi būti portfelyje esančiu akcijų skaičius, siekiant eliminuoti tiek pat nesisteminės rizikos.

Mokslinès diskusijos tebevyksta dèl diversifikavimo efekto išmatavimo sudarant portfelius iš akcijų skirtingais svoriais. Esminių prieštaravimų sukelia mokslinès diskusijos dèl svorių nustatymo sudarant akcijų portfelius siekiant maksimalios diversifikavimo naudos. Turto paskirstymas yra tiek procesas, tiek metodologija, kurie skirti padèti sprendimų prièméjams pasiekti investavimo tikslų, dalijant ribotus išteklius tarp skirtingų alternatyvų (Coyne, 2008). Visi kiekybiniai turto paskirstymo metodai grindžiami ịvairiais apribojimais

Kitas požiūris, vertinant portfelio diversifikavimo laipsnị, kyla iš informacijos teorijos. Woerheide ir Persson (1993) portfelio teorijoje pasinaudojo informacijos teorija ir ekonominès koncentracijos išmatavimo rodikliais, siekdami ivertinti atskiro turto svorio koncentraciją. Ju požiūriu, matuojant portfelio diversifikavimą, turto svoris priklauso ne tik nuo turto skaičiaus, bet ir nuo investuotojo turto dalies. Minèti mokslininkai kritikavo ankstesnius mokslinius tyrimus dẻl to, kad turto skaičius, portfelio diversifikavimo laipsnị atspindi tik tada, kai turto svoriai lygūs. Jie siekẻ surasti rodiklį, kuris tinka iš skirtingų turto svorių sudarytiems portfeliams.

Burnside ir kt. (2004) empiriškai ịrodè, kad geriausi diversifikavimo rezultatai gaunami, kai turto svoriai įvertinami atsižvelgiant ị kapitalizacijos dydị. Šis teiginys galioja, jei rinkos indekse dominuoja labai aukštos ir sąlyginai žemos kapitalizacijos emitentai.

Straipsnio autorès sprendžia mokslinę problemą kaip įvertinti diversifikavimo efektą, kai portfeliai sudaromi iš akcijų skirtingais svoriais bei palygina diversifikavimo efektą abiem minètais atvejais.

Tyrimo objektas - akcijų portfelių diversifikavimo efektas

Tyrimo tikslas - atlikus ankstesnių portfelio diversifikavimo mokslinių tyrimų analizę, ịvertinti diversifikavimo efektą, sudarant akcijų portfelius Lietuvos rinkoje.

Tyrimų metodika originali tuo, kad akcijų atranka ị portfelius vykdoma pagal tokius kriterijus prioriteto tvarka: 1) didžiausios neigiamos koreliacijos koeficientų reikšmès; 2) kiekybinès neigiamų koreliacijų charakteristikos su kitomis akcijų poromis; 3) skirtingiems pramonès sektoriams priklausančių imoniu akcijos. Akciju atrankos ị portfelius procesas identiškas tiek formuojant portfelius lygiais svoriais, tiek skirtingais svoriais.

Diversifikavimo efektas ịvertintas trimis rodikliais: diversifikuojamos rizikos eliminavimo procentu, priklausomai nuo akcijų skaičiaus portfelyje; portfelių rizikos priklausomybe nuo akcijų koncentracijos indekso ir portfelių rizikos priklausomybe nuo akcijų skaičiaus portfelyje. Tyrimai atlikti Lietuvos akciju rinkoje 2009-2010 metais, naudojant vienos dienos akciju kainas.

Tyrimų rezultatai parodè, kad visais atvejais šiek tiek didesnis diversifikavimo efektas gautas, kai portfeliai sudaromi iš akcijų lygiais svoriais. Sudarant tokius portfelius diversifikavimo efektas didejo nuo $39 \%$ iki $98 \%$, o akcijų atranka i portfeli pagal kriterijus prioriteto tvarka (didžiausios neigiamos koreliacijos koeficientu reikšmės; kiekybinès neigiamu koreliaciju charakteristikos su kitomis akciju poromis; skirtingiems pramonès sektoriams priklausančių ịmonių akcijos) pasiteisino tik iki akcijų portfelio, sudaryto iš 22 akcijų. Nuo portfelių, sudarytų daugiau kaip iš 22 akcijų, akcijų atranka nepasiteisino, nes diversifikavimo efektas tai didejjo, tai mažèjo. Taigi, daroma išvada, kad portfelius sudarant iš akcijų lygiais svoriais ir pritaikant autoriu sudarytą akciju atrankos metodika, didẻjant akcijų skaičiui eliminuojama vis didesnè nesisteminès rizikos dalis. Atlikti diversifikavimo efekto tyrimai patvirtino Tang (2004) teiginị, kad diversifikavimo galia atvirkščiai proporcinga portfelio dydžiui. Atkreiptinas dėmesys i tai, kad Tang (2004) portfelių sudarymo metodika yra skirtinga: akcijos parenkamos atsitiktinai, ir sudaromi visi galimi portfelių deriniai pagal akcijų skaičiu juose. Dèl šios priežasties autoriu nustatytas diversifikavimo efektas yra šiek tiek mažesnis, tačiau atkreiptinas demesys, kad Tang (2004) ir autoriu tyrimų rezultatai sutampa, kai portfelis sudarytas iš 22 akcijų, nes eliminuojama $98 \%$ nesisteminès rizikos.

Sudarant akcijų portfelius svoriais, apskaičiuotais pagal vidutinès kapitalizacijos rodiklius, pastebimas toks pats dèsningumas, kaip ir sudarant portfelius vienodais svoriais. Didèjant akcijų skaičiui, tolygiai didejja diversifikuojamos rizikos dalis nuo 36 proc. iki 99 proc. Akcijų atranka ị portfeli pagal minètus kriterijus pasiteisino tik iki akcijų portfelio, sudaryto iš 25 akcijų. Nuo portfeliu, sudarytu daugiau kaip iš 25 akcijų, akcijų atranka nepasiteisino, nes diversifikavimo efektas tai didèjo, tai mažejo.

Tyrimo rezultatai rodo, kad skirtumai tarp diversifikavimo efektų, formuojant portfelius lygiais ir skirtingais akcijų svoriais yra tuo didesni, kuo mažesni portfeliai. Didinant akcijų skaičių portfeliuose, šis skirtumas akivaizdžiai mažèja.

Akcijų portfelių standartinių nuokrypių priklausomybės nuo koncentracijos tyrimo rezultatai parodè, kad esant tiesinei priklausomybei determinacijos koeficientas, kai portfeliai sudaromi iš akcijų lygiais svoriais, yra 0,989, o kai portfeliai sudaromi iš akcijų skirtingais svoriais pagal kapitalizacija - 0,455. Woerheide ir Persson (1993) tyrimo rezultatai parode, kad determinacijos koeficientas, kai portfeliai sudaromi iš akciju lygiais svoriais, yra 0,548. Atkreiptinas dėmesys, kad mokslininkai buvo pasirinkę kitokią portfelių sudarymo metodiką. Akcijų portfelių standartinių nuokrypių priklausomybès nuo akcijų skaičiaus tyrimo rezultatai parodè, kad tiesinio regresinio modelio determinacijos koeficientai yra labai panašūs: 0,479 ir 0,395 (atitinkamai portfeliu, sudarytu iš akciju lygiais ir skirtingais svoriais pagal kapitalizacija). Hiperbolè lygtis abiem atvejais paaiškino daug stipresnę priklausomybę tarp portfelių standartinių nuokrypių ir akcijų skaičiaus juose: 0,989 ir 0,917 (atitinkamai portfelių, sudarytų iš akcijų lygiais ir skirtingais svoriais pagal kapitalizaciją)

Raktažodžiai: portfelio diversifikavimas, diversifikavimo efektas, akciju skaičius, koncentracijos indeksas, vienodu akciju svoriu portfeliai, skirtingu akcijų svoriu portfeliai, kapitalizacija.

The article has been reviewed.

Received in September, 2011; accepted in October, 2012. 